\title{
Prevalent news frames in news reports about military operations against Boko Haram in North-East Nigeria
}

\author{
Ben-Collins Emeka Ndinojuo ${ }^{1}$ \\ Walter Chikwendu Ihejirika \\ University of Port Harcourt, Nigeria \\ Godwin Bassey Okon \\ Rivers State University, Nigeria
}

DOI: 10.30547/worldofmedia.1.2020.3

\begin{abstract}
The media have been accused of bias against the military by framing Boko Haram group as being superior thereby making better-armed soldiers afraid of confronting the group in open battle. This accusation was without any empirical underpinning, thus this study objectives were to identify the framing patterns used by Nigerian newspapers in the coverage of military operations against the Boko Haram group in North-East Nigeria. Four national dailies, Daily Trust, Premium Times, The Nation and Vanguard, were analyzed to find out the framing patterns in the reportage of military operations against Boko Haram to ascertain if the frames were more pro-military or anti-military. Hinged on the framing theory, the research method was content analysis. Inter-coder reliability was tested using the co-efficient of reliability suggested by Chadwick et al. (1984). Findings showed that the Injured/Arrest/Capture/Death of Boko Haram members frame was predominant across three newspapers (Daily Trust, Premium Times, The Nation) which made up $22 \%$ of the frames while Vanguard emphasized Cooperation frame with $11 \%$ of the total frames. Results also indicated that there was a $24 \%$ prevalence of the 17 frame categories used in the study. This shows that Nigerian newspapers reported the military favorably with $80 \%$ of the frames. Overall, findings do not support the statement that the media are to be blamed for the shortcomings of the military in the fight against the insurgents. Other factors like corruption, non-motivation of personnel amongst a host of others should be investigated.
\end{abstract}

\footnotetext{
${ }^{1}$ Corresponding author:

Ben-Collins Emeka Ndinojuo, University of Port Harcourt, University of PMB 5323

Choba, E-W Rd, Port Harcourt, Nigeria.

Email: becoolholly@gmail.com
} 


\section{Keywords}

Frames, content analysis, newspapers, military, Boko Haram, Nigeria.

\section{Introduction}

The Boko Haram conflict in Nigeria has been ongoing since 2009; the protracted nature of the conflict has defied predictions of resolution with millions displaced and thousands killed since it began (Global Terrorism Index, 2018). The media framing of the conflict has been blamed for the continued conflict (Hamid \& Baba, 2014; Olagunju \& Ajadi, 2014; Shehu, 2015). Some reports have argued that newspaper reports have demoralized troops fighting the insurgents (Audu, 2013; Haruna, 2017). The Director of Information, Defence Headquarters, Major General John Enenche claimed that Nigerian troops were reluctant in the past to engage the Boko Haram terrorists because the media framed the Boko Haram group as superior and winning the battle against the military (Erunke, 2017). When appraising the views of Payne (2005) who stated that the media, in the modern era, are indisputably an instrument of war, what Major General Enenche alludes to is the weaponization of the media by the Boko Haram insurgents putting fear in the psyche of Nigerian military officers on the battlefield. Similar misgivings were raised by the US military and authorities over the press coverage of the Vietnam War and this myth was maintained until the 21st century (McMahon, 2000; Shacochis, 2000).

These unsubstantiated allegations against the press were one of the methods the military employed to get the media to tow the government line when reporting conflicts involving the military. This paper attempts to analyze how news about military operations against Boko Haram insurgents has been framed by four Nigerian newspapers in their reports. The paper aimed to identify frames used and news reports about military operations against Boko Haram and identify the dominant frames contained therein to see if they align with statements that the media frame Boko Haram insurgents as being better equipped and stronger than Nigerian soldiers in battle. The justification for studying the newspapers is that because they are independently-owned, there may be a tendency to present reports critical of the government and military in their handling of the Boko Haram conflict and government policy towards the insurgents. To achieve our objective of investigating the frames adopted by the press in their coverage of the conflict, the following research questions were outlined:

1. What are the types of news frames in newspaper reports about military operations against the Boko Haram group in Nigeria? 
2. Which is the dominant frame used in news stories about military operations against Boko Haram whether negative, positive or neutral?

This paper is divided into different headings with the first heading introducing the paper arguments and the research questions. We discuss the newspaper landscape in Nigeria and the newspaper choices for the study. The research is underpinned by the Framing Theory, this is presented and followed by Framing patterns employed to achieve the coding and data collection. Some literature on Framing in Nigeria and how they are intertwined with our research are presented followed by the research methodology. Results, discussion, conclusion, and recommendations follow sequentially to understand the issues and questions raised in the introduction.

\section{Nigerian media landscape}

The newspaper industry in Nigeria has been known to be vibrant dating from the pre-colonial era (1859) through independence (1960), and through successive military regimes (1966-1979, 1983-1999), where it stood against dictatorial regimes, culminating in the return to democracy 1999 and still sustained to date (Adebanwi, 2011; Seng \& Hunt, 1986). Going back, Sommerlad (1966) highlighted that 'Nigeria has not only made progress in this important aspect of national growth and development; it has been made to adopt the press as a political tool, for economic development, stimulation of change and social function'. In the arena of political involvement, the privately-owned newspapers have been more direct and critical in their reportage, because they are devoid of appendages of being government employees; they are not witting players in government propaganda, hence for this study, only private newspaper outfits are used in the data analysis.

The media forms selected for this study are daily newspapers. Four were purposively selected for this research and they include Vanguard, Premium Times, Daily Trust, and The Nation. The primary substance in the choice of newspapers for the study was the prominence of the selected media, as the manifest in their circulation and regional representation. Vanguard was the highest-rated Nigerian newspaper; Premium Times was the most read online newspaper in Nigeria (Alexa, 2017), The Nation was rated as the third-best newspaper in Nigeria (Chigozie, 2013) while Daily Trust was the top-rated newspaper in Northern Nigeria (Shehu, 2015). Newspapers are read beyond their news value, they also serve as sources of textual evidence of immense value to researchers, journalists, students and the society at large, they are informative and Ogbiten (2007) views them as institutions developed by modern civilization to inform 
and lead public opinion on matters of public concern and government policies with an impact on the citizenry.

\section{Framing theory}

Frames according to Reese (2001) 'are organizing principles that are socially shared and persistent over time, that work symbolically to meaningfully structure the social world'. In other to make sense of their output, journalists and media professionals find themselves deconstruct news into frames to make them expressive and comprehensible structures, which earlier authors (Goffman, 1974; Tuchman, 1978) called 'strips'. These denoted 'any arbitrary slice or cut from the stream of ongoing activity' (Goffman, 1974). The media achieves this through processes such as selection, omission, and emphasis. Thus, when journalists select, omit and emphasize certain attributes of news over other attributes, they are framing the story (Fleming-Rife \& Proffitt, 2004). By so doing, they push the audience towards how to think and assimilate their reports.

Some studies (Entman, 1993; Gandy, 1994; Valkenburg \& Semetko, 1999) suggest that media are the definitive news frame producers. The media may achieve this through its ability to influence public thinking and to offer the audience the most crucial topics (Pavelka, 2014). In his 1994 study, Gandy reported that the press preferred to tell audiences to think about the fortunes of Whites and bad news for and about Blacks. Valkenburg \& Semetko (1999) stated that news frames give the audience direction on how to conceive of specific issues or events. Entman (1993) states that a frame 'is really the imprint of power - it registers the identity of actors or interests that competed to dominate the text'. News is also framed as a conflict. The conflict frame emphasizes the conflict between individuals, groups, or institutions (Neuman et al., 1992). Valkenburg \& Semetko (1999) highlighted that this kind of coverage makes winning and losing the central concern.

Hook \& Pu (2006) state that literary studies of news coverage of United States foreign policy reliably reveal patterns of news framing that legitimize the government's perceptions and positions on topical issues as exemplified in the coverage of the Persian Gulf War in 1991 which was characterised by patriotic frames. The media when covering the military operations against Boko Haram insurgents will frame it around whether the Nigerian military is losing or winning the war, words introduced can have a bearing on the readers towards the direction of the conflict. Procurement of new weapons and security agreements with other nations indicate hope for the soldiers fighting such 
insurgents. Scheufele \& Tewksbury (2007) opined that media interpretation of news influences individual perception of the event, and in this case, if the media blow the trumpet of the defeat of Boko Haram, the public may start thinking the group has been defeated and vice versa.

The claim of biased reporting by the Nigerian military against journalists is one that should not be taken lightly. This is because the press played a significant role in the outcome to turn public opinion against the U.S. military in the Vietnam War, regarded in many circles as the most drawn-out and least popular war in modern American history (McMahon, 2000). He observed that Robert Elegant, a correspondent who covered the conflict for the LA Times, charged in a notorious 1981 essay: 'The press was instinctively "against the Government" and, at least reflexively, for Saigon's enemies.... For the first time in modem history, the outcome of a war was determined not on the battlefield, but on the printed page and, above all, on the television screen'.

McMahon (2000) claims further that this indictment resonated with conservative critics who lamented the media's malevolent influence on American society. It also found favor with those looking for a culprit for the abysmal failure of the U.S. military in Vietnam. Coupled with the antiwar movement of the late $60 \mathrm{~s}$ and 70 s, the media seemed a very tempting target. Some veteran reporters, defending their craft and professional colleagues, labeled the press coverage of the war as courageous truth-telling-scrupulously honest, tough-minded, yet also highly patriotic and, in hastening the end of a tragically ill-conceived military operation on a foreign soil, which strategically distinguishes it from the Boko Haram conflict and its coverage which is mainly fought within Nigeria, although dimensions of the conflict has spread into the neighboring West African nations of Nigeria, Chad and Cameroon (Omenma, 2020).

The media reporting military operations against the Boko Haram group may choose to highlight pieces of information that portray government forces as victorious; such as pointing out the casualty estimates of the terrorists while downplaying or out rightly omitting such estimates for the government forces thereby making the enemy casualty figures salient in the report. Entman (1993) defines salience as 'making a piece of information more noticeable, meaningful, or memorable to the audience'. By applying salience to negative aspects of Boko Haram's shortcomings, while omitting those of the military and government forces, it may discourage other Jihadis from faraway places to join the insurgent group in fighting the government.

Freyenberger (2013) provides more clarity by stating that a surge in salience increases the chances that the public will recollect such reported news. Taking 
the cited example of the casualty estimates of Boko Haram from a military operation, the public will tend to remember the figures mentioned, and when such reports are repeated intermittently, it creates an image in the mind of the public that the military is winning the war against the group. Information can be removed or included based on what message the press intends to convey to the audience. The media, therefore, can decide to promote government operations, or the terrorists' agendas, or remain neutral; this is part of our investigation to examine the media agenda if any exists in reporting military operations against the Boko Haram group.

\section{Frame patterns}

Different scholars have come up with different schemes for describing frames in research studies (De Vreese, 2005; Obaje, 2017; Okoro \& Odoemelam, 2013; Semetko \& Valkenburg, 2000) and these different frame types have been applied in different scenarios of framing research depending on the variables under study from framing government policy, environmental issues, and conflicts ranging from corporate conflicts to armed conflicts. The scholars agree that there is no unitary classification of frames, however, what determines framing patterns for each study depends on what the study hopes to achieve and what it intends to analyze. Most of the framing studies on the Boko Haram conflict by scholars in Nigeria have looked up to the works of Semetko \& Valkenburg (2000) and Iyengar (1991) for the frame selection.

Semetko \& Valkenburg (2000) outline that there are essentially two procedures of frame selection, either inductive or deductive approaches. In the inductive method, a sample of the data set is examined to reveal apparent frames embedded in the texts, which are then applied to the generality of the study. The advantage is that it unearths a large number of frames within the text. The deductive method is based on a system of predefined frames selected by the researcher before the study that is expected to be found in the media texts. Its strength is that it is useful when comparing frames across different media sources and is also easily replicable by other researchers, unlike the inductive approach. However, the researcher should avoid the risk of overlooking certain frames that may appear during the process of coding by ensuring that the frames are exhaustive to accommodate all possible frames that have the potential of illuminating the research objectives.

Van Gorp (2007) also asserts that the abstract nature of frames implies that it is best approached by combining qualitative and quantitative research methodology. The literature on framing the Boko Haram crises in Nigeria 
(Obaje, 2017; Okoro \& Odoemelam, 2013) adopted the frames developed in prior studies on framing conflict (De Vreese, 2005; Iyengar, 1991; Semetko \& Valkenburg, 2000). The frames are listed as: Response frame, Powerless frame, Political frame, Human interest, Conspiracy frame, Attribution of responsibility frame, Ethnicity frame, Religious frame, Economic frame, and Labeling frame.

Ngwu et al. (2015) modified their approach to include 'rescue efforts frame, hopelessness frame, political frame, religious frame, ethnic frame, conspiracy frame, and economic frame'. Ita \& Ita (2016) designed their frames to include 'religion, ideology, politics, tribalism, greed, unemployment and illiteracy frames' in describing types of frames they studied. The fundamental difference between this research and the earlier mentioned studies is that whereas they try to frame the Boko Haram insurgency as a whole as perceived by the press and the public, our study is focused on how the media present stories about the military in their efforts in combating the Boko Haram crisis, as some of the frames may not be suitable for our study, hence the need to deductively create frames that take our research objectives into cognizance.

This research employs the framing pattern where we emphasized one of the major actors in the BH conflict in Nigeria - the military. We principally x-rayed the portrayal of the Nigerian military in newspaper reports about military operations against the Boko Haram group. As such, we deductively developed the frames from the framing devices as advocated by Van Gorp (2007) to put the coverage of military operations into context to account for our research objectives. The frames were deductively developed from a sample of the news stories that were analyzed to ensure representation of all the study population in the frames developed. The cumulative documentation of each frame type will reveal the dominant frame pattern.

The frames deductively drawn up were: the win frame, new weapons/ equipment frame, injured/arrest/capture/death of Boko Haram members frame, cooperation frame, rescue frame, mobilization frame, encouragement frame, liberation from, negotiation frame, clarification frame, issues frame, loss frame, helplessness frame, hopelessness frame, tribalism frame, arrest/ capture/death of military frame, and objective frame. After combining frames that have similar emphasis, three master frames were generated to put the study into context; they include the positive, negative and neutral frames.

There were 10 positive frames (the win frame, new weapons frame, injured/arrest/capture/death of BH frame, cooperation frame, rescue frame, mobilization frame, encouragement frame, liberation frame, negotiation frame, and clarification frame) and 6 negative ones (issues frame, lose frame, 
helplessness frame, hopelessness frame, tribalism frame, arrest/capture/death of military). The neutral frame was made up of the objective frame.

\section{Literature review}

Olagunju \& Ajadi (2014) in their treatise titled 'The media and the ideology of insecurity: a critical discourse analysis of two editorials on Federal GovernmentBoko Haram face-off', examined the role of the media in framing the Boko haram crisis using content analysis to study the editorial of two newspapers in NigeriaThe Punch and Daily Trust. Their research revealed that Boko Haram was framed as undefeatable and presented as being more powerful than the government (military) of Nigeria. However, their study was limited to two editorials from the two newspapers. Editorial or personal bias and limiting the study to two editorials could have played a role in their result. Our study explores multiple reports and news stories written over time and is less subjective than editorials which are the newspapers' points of view, unlike straight news stories that are accounts of events, in this case, military events against the Boko Haram group over an extended period.

The research by Ngwu et al. (2015) titled 'Nigerian newspapers framing of the Chibok schoolgirls abduction (a study of the Guardian, Daily Sun, The Daily Trust and Leadership newspapers)' investigated how selected Nigerian newspapers framed the Chibok schoolgirls' abduction of 2014 in two Southern and two Northern Nigerian newspapers (The Guardian, The Sun, The Trust and Leadership). The research objectives were to identify the frames used in coverage of the Chibok girls' abduction and to find out which frame is dominant. Quantitative data for the study were generated with the help of content analysis and survey methods. Content analysis was applied to identify frames types used by journalists in describing the abduction while the survey method was used to measure the influence the frames had on the respondents.

The study established that the selected dailies used rescue efforts frame, hopelessness frame, political frame, religious frame, ethnic frame, conspiracy frame and economic frame with hopelessness frame being the most prevalent. Conclusively, the respondents claimed that the frames adopted by the newspapers have made them believe that the abducted girls were helpless and less likely to be rescued by the government. The frames, however, differ from our study in the sense that the Nigerian military is apolitical with little tolerance for religious or ethnic bias, thus some of the adopted frames do not apply to our study. Our study is also solely content analysis study while they combine the survey method with content analysis. 
Obaje (2017) in her study titled 'News frame patterns: An evaluation of newspaper coverage of Boko Haram attacks in Nigeria' investigated the newspaper coverage of Boko Haram attacks in Nigeria using content analysis. Her objectives included finding out the sizing techniques adopted by the selected newspapers in their coverage of the Boko Haram attacks in Nigeria, the nature of the reports on Boko Haram attacks within the study period and the patterns of news frames of Boko Haram activities in the selected Nigerian newspapers. The researcher used a total of 171 stories from 120 editions from The Nation, Daily Trust, The Guardian and ThisDay using quantitative analysis. Her findings revealed that The Nation published more texts of various genres than the others. She found out that straight news was predominant and stories about Boko Haram attacks occupied the cover pages in lead positions giving them prominence. The government response to the conflict was framed as ineffective because it showcased an uncompromising disposition and its inability to contain the crises.

The research by Okoro \& Odoemelam (2013) titled 'Print media framing of Boko Haram insurgency in Nigeria: A content analytical study of the Guardian, Daily Sun, Vanguard and ThisDay newspapers', identified the pattern of frames used by the named newsprints in their coverage of $\mathrm{BH}$ insurgency using quantitative content analysis. Findings from the study indicated that Nigerian dailies reported the insurgency using the policy response frame predominantly. This highlights that Nigerian newspapers reported government interventions in the conflict positively thereby minimizing the conflict.

A recurring theme among all the reviewed studies is that they all focus on how the media portray the Boko Haram group or their actions against Nigerians or national institutions. The fundamental difference between our research and the reviewed studies is that none of them looked at the specific media portrayal of the military as a very important institution in the fight against Boko Haram. Scholars would rather study the military subsumed under the general term of the Nigerian government which includes the ministries and departments, as well as security units like the Army, Airforce, Department of State Security (DSS), Civil Defense, police, navy, etc. Other hindrances to the war efforts are the corruption of government officials who have used security as a means of enriching themselves at the expense of the lives of the people they swore an oath to protect. The press because of its information provision function has been used to expose such corrupt practices (Aluko, 2017) and in the process have come under attack from the military and other security operatives (Ibekwe, 2017; Ogundipe, 2017). Our study specifically explores the framing of military 
operations and whether they have been positive or negative towards the military as an institution in their efforts to combat the scourge of Boko Haram insurgency and terror acts.

\section{Methodology}

This study made use of content analysis research design. The research populations consisted of the four daily newspapers which were purposively selected, they include Vanguard, Premium Times, Daily Trust, and The Nation and all issues of the selected newspapers from January 1, 2014, to December 31, 2016, including weekend versions amounting to 4384 issues. The sample size of this study was calculated using the algorithm from the website https://www. statisticssolutions.com/sample-size-for-populations.html at a confidence level of $95 \%$. This gave us 353 issues as our sample. To make for even distribution, 7 more issues were added to make the sample 360 .

To ensure equal representation for each sampled newspaper, we used quota sampling to share the sample across the newspapers into 90 issues for each sampled newspaper, and further divided into 30 issues per year for evenness. Systematic random sampling was applied as proposed by (Macnamara, 2011) with an issue selected every 12th day. To further reduce bias, a straw was drawn and January 10, 2014, was selected as the starting point. The unit of analysis for this study is straight news; this study used both quantitative and qualitative techniques in the analysis of the study data.

\section{Data presentation}

Data from the research were collected, analyzed and presented. A total of one hundred and eighty-five (185) stories were coded and analyzed for this study from a sample size of three hundred and sixty (360) issues obtained from the four selected national newspapers in Nigeria between January 1, 2014, and December 31, 2016. The analysis presented is based on news reports about military operations against Boko Haram in Nigeria.

Research question 1: What are the types of news frames in newspaper reports about military operations against the Boko Haram group in Nigeria?

The types of news frames discerned from the news stories are presented in Table 4.12. Seventeen (17) frames in total were used to identify the types of frames used by Nigerian newspaper organizations in framing stories about military operations against the Boko Haram group.

The data from Table 1 show that some frames were more frequently used than others and some frames were not used at all by any of the selected 
newspapers. The table shows that of the 17 frames, 4 were prevalent i.e. they were found across all the newspapers while 13 frames were not found to have been used by all the newspapers. The prevalent frames were; rescue frame, mobilization frame, clarification frame, and issues frame. The frames that were not prevalent include: the win frame, new weapons/equipment frame, injured/arrest/capture/death of Boko Haram members frame, cooperation frame, encouragement frame, liberation frame, negotiation frame, loss frame, arrest/capture/death of military frame, and objective frame, while helplessness frame, hopelessness frame, and tribalism frame were not used by any of the selected newspapers in their news framing military campaigns against Boko Haram.

Table 1

Types of frames

\begin{tabular}{|c|l|c|c|c|c|c|c|}
\hline \multicolumn{2}{|c|}{$\begin{array}{c}\text { Naily } \\
\text { Trust }\end{array}$} & $\begin{array}{c}\text { Premium } \\
\text { Times }\end{array}$ & $\begin{array}{c}\text { The } \\
\text { Nation }\end{array}$ & Vanguard & Total & $\%$ \\
\hline 1 & Win frame & 0 & 5 & 2 & 0 & 7 & 4 \\
\hline 2 & $\begin{array}{l}\text { New weapons/ } \\
\text { Equipment frame }\end{array}$ & 1 & 0 & 0 & 3 & 4 & 2 \\
\hline 3 & $\begin{array}{l}\text { Injured/arrest/ } \\
\text { capture/death of BH }\end{array}$ & 11 & 15 & 15 & 0 & 41 & 22 \\
\hline 4 & Cooperation frame & 0 & 1 & 1 & 18 & 20 & 11 \\
\hline 5 & Rescue frame & 1 & 4 & 3 & 4 & 12 & 7 \\
\hline 6 & Mobilization frame & 3 & 5 & 4 & 5 & 17 & 9 \\
\hline 7 & Encouragement frame & 1 & 0 & 1 & 4 & 6 & 3 \\
\hline 8 & Liberation frame & 0 & 4 & 3 & 3 & 10 & 5 \\
\hline 9 & Negotiation frame & 0 & 2 & 0 & 5 & 7 & 4 \\
\hline 10 & Clarification frame & 7 & 5 & 11 & 1 & 24 & 13 \\
\hline 11 & Issues frame & 2 & 8 & 2 & 12 & 24 & 13 \\
\hline 12 & Loss frame & 0 & 0 & 0 & 6 & 6 & 3 \\
\hline 13 & Helplessness frame & 0 & 0 & 0 & 0 & 0 & 0 \\
\hline 14 & Hopelessness frame & 0 & 0 & 0 & 0 & 0 & 0 \\
\hline 15 & Tribalism frame & 0 & 0 & 0 & 0 & 0 & 0 \\
\hline 16 & $\begin{array}{l}\text { Arrest/capture/death } \\
\text { of military }\end{array}$ & 0 & 5 & 1 & 0 & 6 & 3 \\
\hline 17 & Objective frame & 0 & 0 & 0 & 1 & 1 & 1 \\
\hline & Total & 26 & 54 & 43 & 62 & 185 & 100 \\
\hline
\end{tabular}

$* B H=$ Boko Haram 
The four (4) frames, representing (24\%), were prevalent (i.e, common) in the coverage by the newspapers, while the other frames accounting for $76 \%$ of the frames were not prevalent i.e. were not found in all the newspapers.

Research question 2: Which is the dominant frame used in news stories about military operations against Boko Haram whether negative, positive or neutral?

To determine the dominant frame used in reports for this study, the frame types were separated into the three master frames; positive, negative and neutral frames and presented in Tables 1, 2, 3 and 4, and further summarized by Figure 1.

Table 2

Positive frames

\begin{tabular}{|c|l|c|c|c|c|c|}
\hline \multicolumn{7}{|c|}{ Newspapers } \\
\hline \multicolumn{2}{|c|}{ Types of frames } & $\begin{array}{c}\text { Daily } \\
\text { Trust }\end{array}$ & $\begin{array}{c}\text { Premium } \\
\text { Times }\end{array}$ & $\begin{array}{c}\text { The } \\
\text { Nation }\end{array}$ & Vanguard & Total \\
\hline 1 & Win frame & 0 & 5 & 2 & 0 & 7 \\
\hline 2 & New weapons/Equipment frame & 1 & 0 & 0 & 3 & 4 \\
\hline 3 & $\begin{array}{l}\text { Injured/arrest/capture/ } \\
\text { death of BH }\end{array}$ & 11 & 15 & 15 & 0 & 41 \\
\hline 4 & looperation frame & 0 & 1 & 1 & 18 & 20 \\
\hline 5 & Rescue frame & 1 & 4 & 3 & 4 & 12 \\
\hline 6 & Mobilization frame & 3 & 5 & 4 & 5 & 17 \\
\hline 7 & Encouragement frame & 1 & 0 & 1 & 4 & 6 \\
\hline 8 & Liberation frame & 0 & 4 & 3 & 3 & 10 \\
\hline 9 & Negotiation frame & 0 & 2 & 0 & 5 & 7 \\
\hline 10 & Clarification frame & 7 & 5 & 11 & 1 & 24 \\
\hline \multicolumn{2}{|c|}{ Total } & 24 & 41 & 40 & 43 & 148 \\
\hline
\end{tabular}

Table 3

Negative frames

\begin{tabular}{|c|l|c|c|c|c|c|}
\hline \multicolumn{7}{|c|}{ Newspapers } \\
\hline \multicolumn{2}{|c|}{ Types of frames } & $\begin{array}{c}\text { Daily } \\
\text { Trust }\end{array}$ & $\begin{array}{c}\text { Premium } \\
\text { Times }\end{array}$ & $\begin{array}{c}\text { The } \\
\text { Nation }\end{array}$ & Vanguard & Total \\
\hline 1 & Issues frame & 2 & 8 & 2 & 12 & 24 \\
\hline 2 & loss frame & 0 & 0 & 0 & 6 & 6 \\
\hline 3 & Helplessness frame & 0 & 0 & 0 & 0 & 0 \\
\hline 4 & Hopelessness frame & 0 & 0 & 0 & 0 & 0 \\
\hline 5 & Tribalism frame & 0 & 0 & 0 & 0 & 0 \\
\hline 6 & $\begin{array}{l}\text { Arrest/capture/death } \\
\text { of military }\end{array}$ & 0 & 5 & 1 & 0 & 6 \\
\hline \multicolumn{2}{|l|}{ Total } & 2 & 13 & 3 & 18 & 36 \\
\hline
\end{tabular}


Table 4

\section{Neutral frame}

\begin{tabular}{|c|c|c|c|c|c|c|}
\hline \multicolumn{7}{|c|}{ Newspapers } \\
\hline \multicolumn{2}{|c|}{ Types of frames } & Daily Trust & $\begin{array}{c}\text { Premium } \\
\text { Times }\end{array}$ & The Nation & Vanguard & Total \\
\hline 1 & Objective frame & 0 & 0 & 0 & 1 & 1 \\
\hline \multicolumn{2}{|c|}{ Total } & 0 & 0 & 0 & 1 & 1 \\
\hline
\end{tabular}

Figure 1

\section{Frames in percentage}

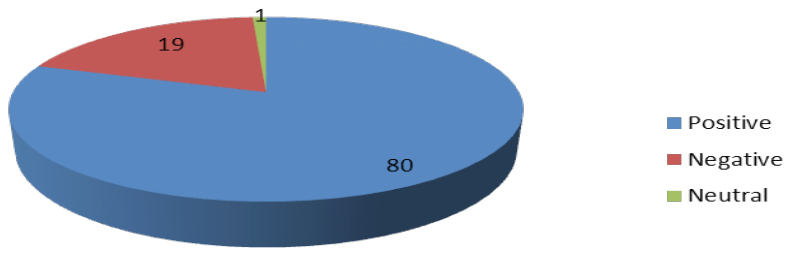

The total mentions identified for positive frames were 148 (80\%), while 36 (19\%) mentions were identified for negative frames and 1 (1\%) mention was identified for the neutral frame. Figure 1 was used to illustrate this information better. From Figure 1, we can see that positive frames were dominant making up $80 \%$ of the frames used in the study analysis, negative frames were $19 \%$ and neutral frames were 1\%. Individually, the Injured/arrest/capture/death of the Boko Haram frame had the most entries with $41(22 \%)$ of the total frames coded for the study.

\section{Discussion of findings}

This research was carried out to determine how Nigerian newspapers framed military operations against the $\mathrm{BH}$ insurgent group, whether positive, negative or neutral. The study had a sample size of 360 editions of four newspapers that were spread evenly over three years revealed 185 news stories. The lower number for Daily Trust could be attributed to the unavailability of some editions from the sample. Some issues of Daily Trust were not available in 2014 (January 10, February 27, March 11 and May 10). The research sample is still valid because the four editions constitute about $4.4 \%$ of the Daily Trust sample and $1.1 \%$ of the total sample population. One edition of The Nation (June 27, 2014) was also unavailable. 
The types of news frames used in stories about military operations against the Boko Haram group in Nigeria

Figure 2 illustrates the frame types used by the selected Nigerian newspapers in their coverage of military campaigns against the $\mathrm{BH}$ insurgent group. The Injured/ arrest/capture/death of Boko Haram members frame had the most entries across all the sample population 41 (22\%), while Helplessness, Hopelessness and Tribalism frames had no entries across the selected newspapers. This implies that Nigerian newspapers are most likely to report about the arrest, capture, injury or death of Boko Haram members in their coverage of military operations against the group while it is highly unlikely that they will describe the military efforts against the group as helpless, hopeless or being plagued by tribalism.

\section{Frame types used by Nigerian newspapers}

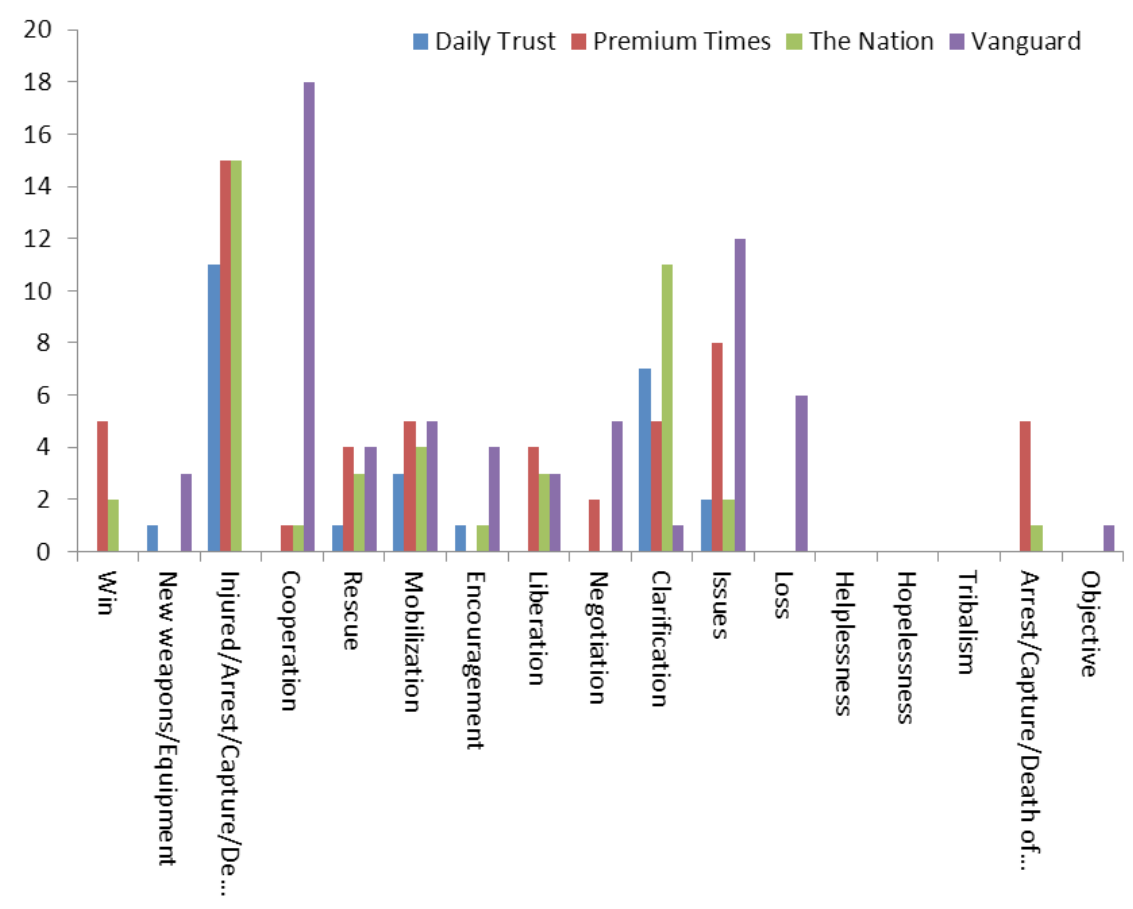

Comparing frame prevalence, this study produced four prevalent frames compared to Okoro \& Odoemelam (2013) that had six prevalent frames and Obaje (2017) that had nine prevalent frames despite the adoption of 17 frames for this research compared to 10 in both studies. The reason could 
be attributed to the limited scope of this research where we studied media texts about military operations against Boko Haram compared to the other scholars that studied media coverage of the Boko Haram conflict in its entirety during the study period. In consonance with Freyenberger (2013) who stated that an increase in salience will result in a corresponding increase in the chances that the public will recollect the reported news, casualty estimates of Boko Haram from military operations were frequently mentioned, and as they are repeated intermittently as seen in our findings, it creates an image in the mind of the public that the military is winning the war against the group.

The research findings indicate that Daily Trust had 7 out of the total 17 frames used in the analysis. This may be attributed to the fact that the newspaper produced the smallest number of articles for analysis. Some of the issues especially those for 2014 were not available because the paper changed its website from http://dailytrust.info to https://www.dailytrust.com.ng in 2014. Thus, articles published in the old website were no longer available to the public. News organizations should find a way to keep their old sites up or ensure that they migrate their archive to new websites when they change their domain names. This will be of immense benefit to researchers who will need such information as reference materials.

Vanguard had the most entries with 11 different frames followed by Premium Times and The Nation with 10 each, while Daily Trust has the least -7 entries. In each of the instances, the newspapers were more likely to report accounts that will enhance military reputation even to the detriment of the journalist's profession.

The dominant frame used in news stories about military operations against Boko Haram in Nigeria

The dominant frame can be deduced from the totality of the analysis as shown in Tables 2, 3, 4 and Figure 1. For further clarity, the findings are summarized below.

Table 5

Summary of frames

\begin{tabular}{|c|l|c|c|c|c|c|c|}
\hline \multicolumn{2}{|c|}{ Newspapers } \\
\hline \multicolumn{2}{|c|}{ Frames } & $\begin{array}{c}\text { Daily } \\
\text { Trust }\end{array}$ & $\begin{array}{c}\text { Premium } \\
\text { Times }\end{array}$ & $\begin{array}{c}\text { The } \\
\text { Nation }\end{array}$ & Vanguard & Total & $\%$ \\
\hline 1 & Positive & 24 & 41 & 40 & 43 & 148 & 80 \\
\hline 2 & Negative & 2 & 13 & 3 & 18 & 36 & 19 \\
\hline 3 & Objective frame & 0 & 0 & 0 & 1 & 1 & 1 \\
\hline \multicolumn{2}{|c|}{ Total } & 26 & 54 & 43 & 62 & 185 & 100 \\
\hline
\end{tabular}


The findings showed that $80 \%$ of the frames used depicted the military positively, while 19\% highlighted the strength of the Boko Haram insurgents by portraying the military negatively. Military casualties were downplayed and agreeing with the pictures where there were no pictures of military casualties in any of the newspapers. The main sources of information about military operations against Boko Haram were the military with little input from journalists as sources. It comes as no surprise that a majority of the stories were framed to portray the military positively compared to the negative ones against them.

Evidenced from the data analyzed from the selected Nigerian newspapers, the study does not agree with Erunke (2017) where the Director of Information, Defence Headquarters, Major General John Enenche claimed that Nigerian troops were reluctant in the past to engage the Boko Haram terrorists because the media framed the Boko Haram group as superior and winning the battle against the military or with other publications (Audu, 2013; Haruna, 2017) that blamed the media for the challenges encountered by the military in the engagements with Boko Haram. There may have been other problems that the soldiers fighting Boko Haram encountered like corruption in government, poor weapons and equipment, poor and late payments of remunerations and allowances that affect the motivation level of soldiers fighting the insurgents and these have been documented in different publications (Aluko, 2017). Although we agree with Payne (2005) that media in the modern era can be made into an instrument of war, findings suggest that it is the military that has turned the press into a war tool against the insurgents with their brand of reportage. Also, like the debunked allegations against the press in the US for their Vietnam War coverage, as documented in Shacochis (2000) and McMahon (2000), we again encountered another unsubstantiated allegation against the Nigerian press in their coverage of military operations against the Boko Haram insurgents.

The findings, however, agree with the views expressed in some literature (Hamid \& Baba, 2014; Olagunju \& Ajadi, 2014; Shehu, 2015) where the media have been blamed for not doing enough in helping to solve the Boko Haram crises by the quality of their reporting. Obaje (2017) recommended a critical interpretation and investigation of crisis reports instead of relying mainly on straight news reporting by including some background and future implications of news events. She adds that newspapers have more or less been spoon-fed information concerning happenings in the North-East instead of being guided by investigative journalism. She concluded by saying that Nigerian media have been adopting more of propaganda than factual and objective reporting and more in 
terms of weapons of mass deception for ideological and commercial purposes. The research reveals favorable reportage by Nigerian newspapers towards the Nigerian military in their war efforts against the Boko Haram group was seen in all the research questions posed in the study and also as recommended in Okoro (2012). The positive frames dominated the negative frames adopted by all the sampled newspapers.

As earlier seen, the media thus have the power to influence their audience's way of thinking and to offer the audience the most important topics (Pavelka, 2014). Concerning military operations against the Boko haram group, the government has consistently insisted on defeating the insurgents and the media has re-echoed this sentiment to a larger extent. Hook \& Pu (2006) earlier stated that research on U.S. foreign policy news coverage consistently reveal patterns that legitimize the government's positions and perceptions of issues. This can be seen from our findings where the majority of the frames reinforce government positions, giving the military agenda some legitimacy, which then becomes the public narrative when the Boko Haram insurgency is in the public purview as seen in news reports.

Moreover, taking into account the views of Scheufele \& Tewksbury (2007), who state that media interpretation of news influences individual perception of the event, and in this case, if the media blows the trumpet of the defeat of Boko Haram, the public starts thinking the group has been defeated. The Boko Haram insecurity in the North East was one of the cardinal talking points of President Buhari when he campaigned against the incumbent President Jonathan before the 2015 elections in Nigeria. Having claimed victory at the polls, President Buhari went ahead to proclaim the defeat of the terrorist group in 2015 and 2016, it came as a rude awakening to discover that the group can kidnap hundreds of schoolgirls to spread their terror of discouraging western education especially among women.

\section{Conclusion}

The research has added to the body of work about newspaper coverage of the Boko Haram insurgency by focusing on how military operations are reported in four Nigerian newspapers. The findings have shown contrasts in newspaper coverage and framing of the military when reporting about campaigns against Boko Haram, and how the military has been presented in these reports. The study has also been able to show the dominant and prevalent frames used by the newspapers in their coverage. A significant contribution of this study, not found in previous literature is the military focus of the research which came 
from the statement credited to the former Director of Defense Headquarters, Major-General John Enenche who claimed that the media framed Boko haram as being superior to the military thus making the soldiers unable to confront the insurgents in battle. The study was able to show that the media have framed the military positively and in some cases against some established journalism ethics and principles. In other words, the Nigerian military can be said to have turned the media to work for and with them in reporting military operations against the insurgents.

The study found a disparity in frame patterns used by the newspapers in their reportage of military operations against the Boko Haram group between 2014 and 2016. Daily Trust, Premium Times and The Nation newspapers emphasized the Injured/arrest/capture/death of Boko Haram members making up 22\% of the frames while Vanguard emphasized cooperation frame accounting for $11 \%$ of the total frames. Four (4) frames, representing (24\%), were prevalent (i.e common) in the coverage by the newspapers. These frames included the following: Rescue frame, Mobilization frame, Clarification frame, and Issues frame. The other frames accounting for $76 \%$ of the frames were not prevalent i.e. were not found in all the newspapers. Overall the findings show that frames showing the military in a positive light were dominant with $80 \%$ of the total frames. In addressing the types of news frames discernable from newspaper reports, the frame that emphasizes harm, capture or death of Boko Haram insurgents stands out among the framing group for this study. In other words, newspapers would put injury to Boko Haram members than harm to soldiers of the Nigerian government forces fighting the insurgents, thus showing an aversion to positively present reports about government forces over the militant insurgents, and at the same time keeping reporting about challenges faced by the military against the insurgents at a minimum.

\section{Recommendations}

The study recommends that the Nigerian press should continue the practice of using frames that highlight the strength of the government (military) over terrorist organizations. Frames promoting peace, government policy actions and response to setbacks should be promoted over those capable of causing chaos and confusion in the polity. Premium Times and Vanguard should also reduce the number of negative frames in their stories. Although they may be reporting reality, such reports should be written with government successes as the main thrusts of the message. The fabric of Nigeria as a fragile, secular and multicultural society coupled with the roles played by ethnicity and religion 
can be distorted by one negative report, which can be interpreted differently by various groups.

Further studies can also be carried out to find out the consistency of the findings using more recent data as well as expanding the framing categories and also the inclusion of other media forms like television, radio, and magazines to broadly generalize and understand the dynamics of how Nigerian media reports military operations against the Boko Haram insurgent group. Other studies could also be expanded to cover other crises like the Fulani Herdsmen violence, Niger Delta militants and the Biafra agitations in the southern part of Nigeria.

\section{References}

ADEBANWI, W. (2011). The radical press and security agencies in Nigeria: Beyond hegemonic polarities. African Studies Review, 54(3), 45-69.

ALEXA (2017). The top 500 sites on the web. Available from: http://www. alexa.com/topsites/category/Top/Regional/Africa/Nigeria/News_and_Media/ Newspapers

ALUKO, O. (2017). Anonymous soldier writes Buhari, alleges gross corruption. The Punch. Available from: http://punchng.com/anonymous-soldier-writesbuhari-alleges-gross-corruption/

AUDU, O. (2013). Nigerian military shut GSM telecommunications in Maiduguri in hunt for Boko Haram. Premium Times. Available from: http:// www.premiumtimesng.com/news/13476-nigerian-military-shut-gsmtelecommunications-in-maiduguri-in-hunt-for-boko-haram.html

CHIGOZIE, E. (2013). Top 10 Nigerian newspapers (most read online). Available from: https://answersafrica.com/top-10-nigerian-newspapers-most-read-online.html

DE VREESE, C. H. (2005). News framing: Theory and typology. Information Design Journal + Document Design, 13(1), 51-62.

ENTMAN, R. M. (1993). Framing: Toward clarification of a fractured paradigm. Journal of Communication, 43(4), 51-58.

ERUNKE, J. (2017). Boko Haram: Why troops were refusing to go to battle front DHQ. Vanguard. Available from: http://www.vanguardngr.com/2017/03/bokoharam-troops-refusing-go-battle-front-dhq/

FLEMING-RIFE, A. \& PROFFITT, J. M. (2004). The more public school reform changes, the more it stays the same: A framing Analysis of the newspaper coverage of Brown v. board of education. The Journal of Negro Education, 73(3), pp. 239-254.

FREYENBERGER, D. (2013). Amanda Knox: A content analysis of media framing in newspapers around the world. Electronic Theses and Dissertations. Paper 1117. Available from: http://dc.etsu.edu/etd/1117 
GANDY, O. H., Jr. (1994). Covering America: From bad to worse: The media's framing of race and risk. Media Studies Journal, 8, 39-48.

Global Terrorism Index (2018). 2018 Global Terrorism Index: Deaths from terrorism down 44 percent in three years, but terrorism remains widespread. Sydney, New York, The Institute for Economics and Peace.

GOFFMAN, E. (1974). Frame analysis: An essay on the organization of experience. Boston, Northeastern University Press.

HARUNA, A. (2017). Boko Haram: Nigerian troops owed two months allowances cry out. Premium Times. Available from: https://www.premiumtimesng.com/ regional/nnorth-east/246020-boko-haram-nigerian-troops-owed-two-monthsallowances-cry.html/amp

HAMID, A. M. \& BABA, I. M. (2014). Resolving Nigeria's 'Boko Haram' insurgence: What role for the media? Social and Behavioral Sciences, 155, 14-20.

HOOK, S. W. \& PU, X. (2006). Framing Sino-American relations under stress: A reexamination of news coverage of the 2001 spy plane crisis. Asian Affairs, 33(3), 167-183.

IBEKWE, N. (2017). Nigerian army vows to charge PREMIUM TIMES for 'fraudulently obtaining' military information. Sahara Reporters, 24 $4^{\text {th }}$ January, 2017. Available from: http://saharareporters.com/2017/01/24/nigerian-armyvows-charge-premium-times-\%E2\%80\%98fraudulently-obtaining\%E2\%80\%99military-information

ITA, O. J. \& ITA, E. P. (2016). Newspaper framing and University of Uyo students' perception of Boko Haram insurgency in Nigeria. International Journal of Advanced Research in Public Policy, Administration and Development Strategies, 2(1), 94-108.

IYENGAR, S. (1991). Is anyone responsible? How television frames political issues. Chicago, University of Chicago Press.

MACNAMARA, J. (2011). Media content analysis: Its uses, benefits and best practice methodology. Asia Pacific Public Relations Journal, 6(1), 1-34.

MCMAHON, R. J. (2000). The Pentagon's war, the media's war. Reviews in American History, 28(2), 303-308.

NEUMAN, W. R., JUST, M. R., \& CRIGLER, A. N. (1992). Common knowledge. Chicago, University of Chicago Press.

NGWU, C., EKWE, O., \& CHIAHA, C. (2015). Nigerian newspapers framing of the Chibok school girls' abduction (a study of The Guardian, Daily Sun, The Trust and Leadership newspapers). Global Journal of Arts, Humanities and Social Sciences, 3(8), 78-93.

OBAJE, C. E. (2017). News frame patterns: An evaluation of newspaper coverage of Boko Haram attacks in Nigeria. Covenant Journal of Communication, 4(1), 1-25. 
OGBITEN, B (2007). Newspaper readership in Port Harcourt. International Journal of Communication, 6, 12-26.

OGUNDIPE, S. (2017). Nigerian police detain Premium Times publisher, journalist on 'orders from above'. Premium Times, 19th January, 2017. Available from: http://www.premiumtimesng.com/news/headlines/221029-nigerian-policedetain-premium-times-publisher-journalist-orders.html

OKORO, N. \& ODOEMELAM, C. (2013). Print media framing of Boko Haram insurgency in Nigeria: A content analytical study of the Guardian, Daily Sun, Vanguard and ThisDay newspapers. Research on Humanities and Social Sciences, 3(11), 86-94.

OLAGUNJU, F. B. \& AJADI, R. A. (2014). The media and the ideology of insecurity: A critical discourse analysis of two editorials on federal governmentBoko Haram face-off. Review of Journalism and Mass Communication, 2(1), 33-46.

OMENMA, J. T. (2020). Untold story of Boko Haram insurgency: The Lake Chad oil and gas connection. Politics and Religion, 13(1), 180-213.

PAYNE, K. (2005). Media as an instrument of war. Parameters, 35, 81-93.

PAVELKA, J. (2014). The factors affecting the presentation of events and the media coverage of topics in the mass media. Social and Behavioral Sciences, 140, 623-629.

REESE, S. D. (2001). Prologue - araming public life. In: S. D. Reese, O. H. Gandy, Jr., \& A. E. Grant, Framing public life: Perspectives on media and our understanding of the social world, pp. 139-161. Mahwah, NJ, Erlbaum.

SCHEUFELE, D. A. \& TEWKSBURY, D. (2007). Framing, agenda setting, and priming: The evolution of three media effects models. Journal of Communication, 57(1), 9-20.

SENG, M. P. \& HUNT, G. T. (1986). The press and politics in Nigeria: A case study of developmental journalism. Boston College Third World Law Journal, 6(2), 85-110.

SHACOCHIS, B. (2000). Pens and swords: A positive dynamic for the US media and military. Harvard International Review, 22(1), 26-30.

SHEHU, A. (2015). Press coverage of the Boko Haram insurgency and its implications for conflict-sensitive journalism in Nigeria (2013/2014). Dissertation submitted to the School of Post Graduate Studies, Ahmadu Bello University, Zaria, Nigeria.

SOMMERLAD, E. L. (1966). The press in developing countries. Sydney, Sydney University Press.

TUCHMAN, G. (1978). Making news. A study in the construction of reality. New York, Free Press. 
VALKENBURG, P. M., \& SEMETKO, H. A. (1999). The effects of news frames on readers' thoughts and recall. Communications Research, 26, pp. 550-569.

VAN GORP, B. (2007). The constructionist approach to framing: Bringing culture back in. Journal of Communication, 57, pp. 60-78. DOI:10.1111/j.14602466.2006.00329.x 